Article

\title{
Gene Expression Profiling in Huntington's Disease: Does Comorbidity with Depressive Symptoms Matter?
}

\author{
Gabriela Delevati Colpo ${ }^{1}$, Natalia Pessoa Rocha ${ }^{2,3}$, Erin Furr Stimming ${ }^{2,3}$ \\ and Antonio Lucio Teixeira $1,2,4, *$ (D) \\ 1 Neuropsychiatry Program, Louis A Faillace Department of Psychiatry and Behavioral Sciences, McGovern \\ Medical School, The University of Texas Health Science Center at Houston, Houston, TX 77054, USA; \\ Gabriela.D.Colpo@uth.tmc.edu \\ 2 HDSA Center of Excellence at The University of Texas Health Science Center at Houston, \\ Houston, TX 77030, USA; Natalia.PessoaRocha@uth.tmc.edu (N.P.R.); Erin.E.Furr@uth.tmc.edu (E.F.S.) \\ 3 Department of Neurology, McGovern Medical School, The University of Texas Health Science Center at \\ Houston, Houston, TX 77030, USA \\ 4 Instituto de Ensino \& Pesquisa, Santa Casa BH, Belo Horizonte 30150-221, Brazil \\ * Correspondence: antonio.l.teixeira@uth.tmc.edu; Tel.: +1-713-486-2622
}

Received: 25 September 2020; Accepted: 9 November 2020; Published: 11 November 2020

\begin{abstract}
Huntington's disease (HD) is an inherited neurodegenerative disease. Besides the well-characterized motor symptoms, HD is marked by cognitive impairment and behavioral changes. In this study, we analyzed the blood of HD gene carries using RNA-sequencing techniques. We evaluated samples from HD gene carriers with $(n=8)$ and without clinically meaningful depressive symptoms $(n=8)$ compared with healthy controls $(n=8)$. Groups were age- and sex-matched. Preprocessing of data and between-group comparisons were calculated using DESeq2. The Wald test was used to generate $p$-values and $\log 2$ fold changes. We found 60 genes differently expressed in HD and healthy controls, of which 21 were upregulated and 39 downregulated. Within HD group, nineteen genes were differently expressed between patients with and without depression, being 6 upregulated and 13 downregulated. Several of the top differentially expressed genes are involved in nervous system development. Although preliminary, our findings corroborate the emerging view that in addition to neurodegenerative mechanisms, HD has a neurodevelopmental component. Importantly, the emergence of depression in HD might be related to these mechanisms.
\end{abstract}

Keywords: Huntington's disease; neurodegenerative disease; RNA-seq; depression; neurodevelopment

\section{Introduction}

Huntington's disease (HD) is an inherited autosomal dominant neurodegenerative disease. HD is caused by expanded CAG trinucleotide repeats in the exon 1 of the Huntingtin gene (HTT), which encodes a mutant form of the huntingtin protein (HTT) with an abnormal polyglutamine tail at the $\mathrm{N}$-terminus [1-3]. HTT is an important protein for neurodevelopment. The knockout of the HTT in mice results in major brain abnormalities and death soon after birth [4-6]. In addition, depletion of wild-type HTT in the postnatal mouse brain leads to progressive neurodegeneration [7]. The presence of 40 or more CAG repeats invariably causes the disease, and longer repeats predict earlier disease onset. Mutant HTT (mHTT) is widely expressed and believed to induce neurodegeneration through different mechanisms, including abnormal interaction with other proteins, leading to cellular changes and ultimately cell death [8]. 
HD is marked by a triad of symptoms including motor, cognitive and psychiatric or behavioral symptoms. The clinical diagnosis of HD has been historically based on motor symptoms. However, cognitive and psychiatric symptoms are often present years prior to the onset of clinically relevant motor symptoms [9]. Psychiatric symptoms, such as anxiety, irritability, impulsivity, and depressed mood are frequent in individuals with HD and can be quite troublesome. Major depression is the most common psychiatric syndrome among premanifest HD carriers [10]. Depression may precede the onset of typical motor symptoms by 4 to 10 years, making it one of the earliest signs possibly related to HD pathophysiology. Moreover, around $40-50 \%$ of patients with HD experience depression at some point during the course of the disease [11], and many patients and their relatives consider this problem the most distressing aspect of the illness. Actually, depression seems to influence more profoundly health-related quality of life in HD than motor symptoms or cognitive dysfunction [12]. The presence of depression in HD is also an important predictor of suicidal behavior [13]. Patients with HD have been shown to commit suicide four to eight times more often than the general population [14-16]. The increased rate of suicide may be related to several factors, including the emotional distress of having an incurable disease alongside the elevated frequency of depression and other behavioral symptoms, such as impulsivity $[13,17]$.

The reasons for the frequent co-occurrence of $\mathrm{HD}$ and depression are still unclear. The heritability nature of HD does not fully explain the high prevalence of psychiatric symptoms, especially depression, in HD $[18,19]$. Importantly, as the severity of depression is not associated with disease progression [20-22], different mechanisms are likely to affect neurons involved in mood regulation circuits and neurons involved in motor skills that are impaired in manifest or later stages of the disease. The molecular underpinnings of psychiatric symptoms in HD are poorly understood. Therefore, we designed an exploratory study to investigate peripheral blood gene expression profile through RNA-seq in HD gene carriers (with and without depression) and healthy controls. Our hypothesis is that HD gene carriers presenting with depression have a different transcriptome profile when compared with HD gene carriers without these symptoms. In addition, we assessed different genetic pathways underlying HD in comparison with healthy controls. This is the first study to evaluate gene expression profile comparing these subgroups of HD gene carriers and healthy controls. Our results advance the understanding of the biological mechanisms associated with depression in HD with the ultimate goal of identifying a more specific and effective anti-depressant strategy to improve the quality of life and decrease suicide rates of these subjects [23].

\section{Results}

Demographic data from HD gene carriers and controls are shown in Table 1. Groups did not differ in age, years of education, sex and BMI.

Table 1. Demographic variables of the subjects enrolled in this study.

\begin{tabular}{ccccc}
\hline Variables & $\begin{array}{c}\text { Control Group } \\
(\boldsymbol{n}=\mathbf{8})\end{array}$ & $\begin{array}{c}\text { HD without } \\
\text { Depression }(\boldsymbol{n}=\mathbf{8})\end{array}$ & $\begin{array}{c}\text { HD with } \\
\text { Depression }(\boldsymbol{n}=\mathbf{8})\end{array}$ & Statistic \\
\hline Female sex & $5(62.5 \%)$ & $5(62.5 \%)$ & $5(62.5 \%)$ & $\begin{array}{c}\chi 2(1)=0 \\
p=1\end{array}$ \\
\hline Age & $51.91(10.59)$ & $38.17(8.44)$ & $48.27(13.81)$ & $\begin{array}{c}\mathrm{F}(2,21)=3.12 \\
p=0.067\end{array}$ \\
\hline Years of education & $15.93(4.82)$ & $15.57(3.59)$ & $14.25(2.96)$ & $\begin{array}{c}\mathrm{F}(2,21)=0.4078 \\
p=0.6703\end{array}$ \\
\hline BMI & $30.86(8.09)$ & $29.04(7.15)$ & $29.39(6.18)$ & $\begin{array}{c}\mathrm{F}(2,20)=0.3627 \\
p=0.7003\end{array}$ \\
\hline
\end{tabular}




\subsection{Differential Gene Expression Analysis}

Sixty genes were differently expressed in HD gene carriers $(n=16)$ compared with healthy controls $(n=8)$, of which 21 were upregulated and 39 were downregulated (Table 2). When analyzing HD gene carriers with depression versus non-depression, there were 19 genes differently expressed, being 6 upregulated and 13 downregulated (Table 3).

Table 2. Different expressed genes between HD gene carrier and healthy controls.

\begin{tabular}{|c|c|c|c|c|c|}
\hline Gene ID & Gene Name & log2FoldChange & Stat & $p$ Value & padj \\
\hline ENSG00000109956 & B3GAT1 & 1.484 & 4.332 & 0.000 & 0.019415 \\
\hline ENSG00000205336 & ADGRG1 & 1.293 & 4.605 & 0.000 & 0.019415 \\
\hline ENSG00000165568 & AKR1E2 & -1.007 & -4.185 & 0.000 & 0.026784 \\
\hline ENSG00000206172 & HBA1 & -1.208 & -3.890 & 0.000 & 0.038152 \\
\hline ENSG00000110203 & FOLR3 & -1.687 & -3.265 & 0.001 & 0.059707 \\
\hline ENSG00000234389 & AC007278.1 & -1.262 & -3.162 & 0.002 & 0.068408 \\
\hline ENSG00000137267 & TUBB2A & -1.591 & -2.213 & 0.027 & 0.192338 \\
\hline ENSG00000196565 & HBG2 & -1.006 & -2.166 & 0.030 & 0.201445 \\
\hline ENSG00000239839 & DEFA3 & 1.101 & 2.017 & 0.044 & 0.234289 \\
\hline ENSG00000237973 & MTCO1P12 & 2.565 & 3.763 & 0.000 & NA \\
\hline ENSG00000248527 & MTATP6P1 & 1.036 & 3.042 & 0.002 & NA \\
\hline ENSG00000162631 & NTNG1 & -1.102 & -2.618 & 0.009 & NA \\
\hline ENSG00000196539 & OR2T3 & -1.329 & -3.064 & 0.002 & NA \\
\hline ENSG00000200488 & RN7SKP203 & -1.059 & -2.842 & 0.004 & NA \\
\hline ENSG00000071909 & MYO3B & 1.142 & 2.789 & 0.005 & NA \\
\hline ENSG00000144485 & HES6 & -1.141 & -3.027 & 0.002 & NA \\
\hline ENSG00000144908 & ALDH1L1 & -1.288 & -2.189 & 0.029 & NA \\
\hline ENSG00000145362 & ANK2 & -1.017 & -1.961 & 0.050 & NA \\
\hline ENSG00000178636 & AC092656.1 & -1.233 & -3.359 & 0.001 & NA \\
\hline ENSG00000247199 & AC091948.1 & -1.128 & -4.107 & 0.000 & NA \\
\hline ENSG00000230202 & AL450405.1 & 2.670 & 4.467 & 0.000 & NA \\
\hline ENSG00000260997 & AC004847.1 & 1.032 & 3.541 & 0.000 & NA \\
\hline ENSG00000075213 & SEMA3A & -1.025 & -2.605 & 0.009 & NA \\
\hline ENSG00000279483 & AC090498.1 & -1.257 & -2.763 & 0.006 & NA \\
\hline ENSG00000276819 & TRBV15 & -1.360 & -3.558 & 0.000 & NA \\
\hline ENSG00000201098 & RNY1 & -1.164 & -2.702 & 0.007 & NA \\
\hline ENSG00000234449 & FAM239A & -2.310 & -2.901 & 0.004 & NA \\
\hline ENSG00000215374 & FAM66B & -1.026 & -4.054 & 0.000 & NA \\
\hline ENSG00000240905 & RN7SL798P & 1.118 & 3.315 & 0.001 & NA \\
\hline ENSG00000184350 & MRGPRE & -1.929 & -2.127 & 0.033 & NA \\
\hline ENSG00000006071 & $\mathrm{ABCC} 8$ & -1.368 & -2.151 & 0.031 & NA \\
\hline ENSG00000170959 & DCDC1 & -1.127 & -2.440 & 0.015 & NA \\
\hline ENSG00000156113 & KCNMA1 & -1.153 & -2.707 & 0.007 & NA \\
\hline ENSG00000235602 & POU5F1P3 & 1.022 & 3.920 & 0.000 & NA \\
\hline ENSG00000225231 & LINC02470 & -1.765 & -2.060 & 0.039 & NA \\
\hline ENSG00000177359 & AC024940.2 & -1.687 & -3.254 & 0.001 & NA \\
\hline ENSG00000273824 & AC008033.3 & 1.148 & 2.862 & 0.004 & NA \\
\hline ENSG00000123201 & GUCY1B2 & -1.532 & -3.138 & 0.002 & NA \\
\hline
\end{tabular}


Table 2. Cont.

\begin{tabular}{lccccc}
\hline Gene ID & Gene Name & log2FoldChange & Stat & $p$ Value & padj \\
\hline ENSG00000102837 & OLFM4 & 1.081 & 2.248 & 0.025 & NA \\
\hline ENSG00000139926 & FRMD6 & -1.146 & -3.784 & 0.000 & NA \\
\hline ENSG00000021645 & NRXN3 & -1.020 & -2.433 & 0.015 & NA \\
\hline ENSG00000189419 & SPATA41 & -1.037 & -3.232 & 0.001 & NA \\
\hline ENSG00000205918 & PDPK2P & 1.111 & 3.006 & 0.003 & NA \\
\hline ENSG00000261245 & AC093520.2 & 1.096 & 2.797 & 0.005 & NA \\
\hline ENSG00000270124 & AC092127.2 & 1.040 & 3.505 & 0.000 & NA \\
\hline ENSG00000262074 & SNORD3B-2 & -1.154 & -2.194 & 0.028 & NA \\
\hline ENSG00000276241 & AC243829.2 & 1.579 & 3.073 & 0.002 & NA \\
\hline ENSG00000274512 & TBC1D3L & 1.021 & 2.304 & 0.021 & NA \\
\hline ENSG00000142449 & FBN3 & -1.148 & -1.982 & 0.047 & NA \\
\hline ENSG00000187244 & BCAM & -1.063 & -2.163 & 0.031 & NA \\
\hline ENSG00000262874 & C19orf84 & 1.224 & 3.628 & 0.000 & NA \\
\hline ENSG00000233493 & TMEM238 & -1.064 & -4.849 & 0.000 & NA \\
\hline ENSG00000179954 & SSC5D & -1.192 & -2.558 & 0.011 & NA \\
\hline ENSG00000196263 & ZNF471 & -1.153 & -3.938 & 0.000 & NA \\
\hline ENSG00000211659 & IGLV3-25 & -1.369 & -3.483 & 0.000 & NA \\
\hline ENSG00000264063 & MIR3687-2 & -1.068 & -2.784 & 0.005 & NA \\
\hline ENSG00000215533 & LINC00189 & 1.417 & 2.738 & 0.006 & NA \\
\hline ENSG00000236056 & GAPDHP14 & 1.401 & 2.836 & 0.005 & NA \\
\hline ENSG00000255568 & BRWD1-AS2 & -1.119 & -3.732 & 0.000 & NA \\
\hline ENSG00000210049 & MT-TF & 1.037 & 2.638 & 0.008 & NA \\
\hline & Stat: statistics; padj: $p$ value adjustable. & & \\
\hline
\end{tabular}

\subsection{Gene Ontology Analysis}

Comparing HD gene carriers and healthy controls, 109 enriched pathways were identified (Table 4). Among the enriched pathways, many of them contain the top differentially expressed gene ADGRG1, such as GO:0010573 vascular endothelial growth factor production, GO:0021801 cerebral cortex radial glia guided migration, GO:0021796 cerebral cortex regionalization GO:0021819 layer formation in cerebral cortex. Noteworthy, there were other enriched pathways with different genes involved in neurodevelopment, such as the GO:2001224 positive regulation of neuron migration and GO:0007155 cell adhesion.

In the comparison among HD gene carriers, 61 enriched pathways were identified (Table 5). Several pathways have the NECTIN2 gene, as GO:0002891 positive regulation of immunoglobulin mediated immune response, GO:0034332 adherens junction organization, GO:0007157 heterophilic cell-cell adhesion via plasma membrane cell adhesion molecules. 
Table 3. Different expressed genes between HD gene carrier with depression and HD gene carrier without depression.

\begin{tabular}{lccccc}
\hline Gene ID & Gene Name & log2FoldChange & Stat & $p$ Value & padj \\
\hline ENSG00000130202 & NECTIN2 & -1.20871551 & -2.27773 & 0.022743 & 0.999462 \\
\hline ENSG00000235169 & SMIM1 & 1.286216213 & 2.0662 & 0.03881 & 0.999462 \\
\hline ENSG00000163646 & CLRN1 & -1.417542862 & -2.08074 & 0.037458 & 0.999462 \\
\hline ENSG00000233058 & LINC00884 & -1.037747878 & -2.89202 & 0.003828 & 0.999462 \\
\hline ENSG00000010030 & ETV7 & 1.070004254 & 2.301148 & 0.021383 & 0.999462 \\
\hline ENSG00000215018 & COL28A1 & -1.217119591 & -2.50457 & 0.01226 & 0.999462 \\
\hline ENSG00000175445 & LPL & 1.308483772 & 2.189831 & 0.028537 & 0.999462 \\
\hline ENSG00000178860 & MSC & -1.100681038 & -2.98191 & 0.002865 & 0.999462 \\
\hline ENSG00000159247 & TUBBP5 & -1.267966389 & -2.35356 & 0.018595 & 0.999462 \\
\hline ENSG00000196565 & HBG2 & -1.350354678 & -2.52451 & 0.011586 & 0.999462 \\
\hline ENSG00000251381 & LINC00958 & 2.26201877 & 2.3048 & 0.021178 & 0.999462 \\
\hline ENSG00000254789 & AC073172.1 & -1.332994545 & -2.7906 & 0.005261 & 0.999462 \\
\hline ENSG00000255508 & AP002990.1 & -1.058759746 & -3.49951 & 0.000466 & 0.999462 \\
\hline ENSG00000078114 & NEBL & 2.623958542 & 3.216931 & 0.001296 & 0.999462 \\
\hline ENSG00000200830 & RN7SKP134 & -1.036440243 & -2.74592 & 0.006034 & 0.999462 \\
\hline ENSG00000135116 & HRK & -1.007746896 & -2.79251 & 0.00523 & 0.999462 \\
\hline ENSG00000124107 & SLPI & -1.250074721 & -2.10266 & 0.035496 & 0.999462 \\
\hline ENSG00000226025 & AC005515.1 & 1.025633489 & 2.438544 & 0.014747 & 0.999462 \\
\hline ENSG00000160233 & LRRC3 & -1.09935177 & -2.93576 & 0.003327 & 0.999462 \\
\hline & & & &
\end{tabular}

Stat: statistics; padj: $p$ value adjustable.

\subsection{Validation of Microarray Data by Real-Time $q P C R$}

We validated the RNA-seq results by determining mRNA levels of the top three differentially expressed genes (Figure 1). Regarding ADGRG1 and B3GAT1, real-time qPCR confirmed RNAseq results. For NECTIN2, the results showed the same tendency, but without reaching statistical significance.

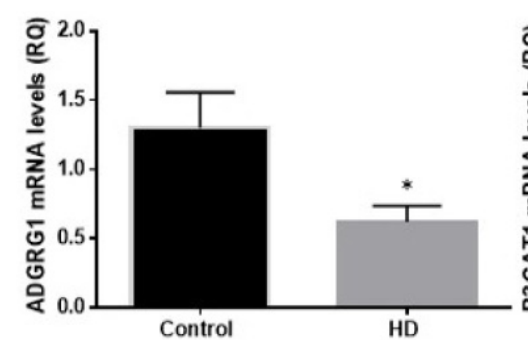

Control

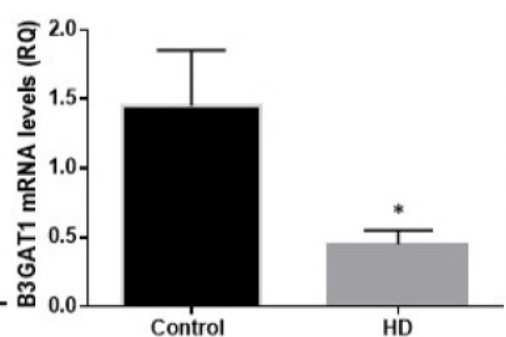

Control

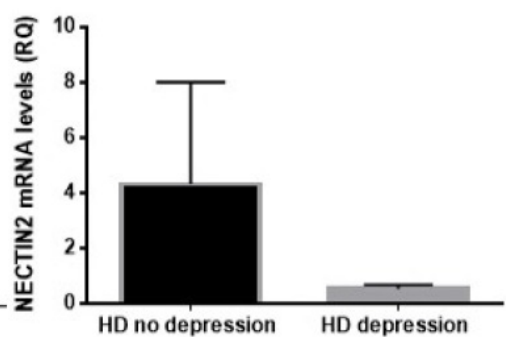

HD no depression HD depression

Figure 1. mRNA levels of the top three differentially expressed genes. * $p<0.05$. 
Table 4. The 20 most significant different pathways between HD gene carriers and healthy control.

\begin{tabular}{|c|c|c|c|c|c|c|}
\hline Genes & Process_Name & $\begin{array}{l}\text { Significant_- } \\
\text { Genes_Count }\end{array}$ & $\begin{array}{l}\text { Total_Genes_ } \\
\text { Group_Count }\end{array}$ & $\begin{array}{c}\text { Percent_- } \\
\text { Significant_Genes }\end{array}$ & $p$-Value & padj-Value \\
\hline HBG2; HBA1; & GO:0015671 oxygen transport & 2 & 14 & 14.286 & 0.00013 & 0.013186 \\
\hline ANK2; ABCC8; & $\begin{array}{c}\text { GO:0043268 positive regulation of } \\
\text { potassium ion transport }\end{array}$ & 2 & 10 & 20.000 & 0.00007 & 0.013186 \\
\hline ANK2; SEMA3A; & GO:0002027 regulation of heart rate & 2 & 31 & 6.452 & 0.00058 & 0.026314 \\
\hline FRMD6; & GO:0003383 apical constriction & 1 & 3 & 33.333 & 0.00427 & 0.026314 \\
\hline ABCC8; KCNMA1; & $\begin{array}{c}\text { GO:0006813 potassium ion } \\
\text { transport }\end{array}$ & 2 & 78 & 2.564 & 0.00337 & 0.026314 \\
\hline SSC5D; IGLV3-25; HBA1; & $\begin{array}{c}\text { GO:0006898 receptor-mediated } \\
\text { endocytosis }\end{array}$ & 3 & 185 & 1.622 & 0.00110 & 0.026314 \\
\hline ALDH1L1; & $\begin{array}{l}\text { GO:0009258 10-formyltetrahydrofolate } \\
\text { catabolic process }\end{array}$ & 1 & 2 & 50.000 & 0.00321 & 0.026314 \\
\hline ADGRG1; & $\begin{array}{l}\text { GO:0010573 vascular endothelial } \\
\text { growth factor production }\end{array}$ & 1 & 3 & 33.333 & 0.00427 & 0.026314 \\
\hline ADGRG1; & $\begin{array}{l}\text { GO:0021801 cerebral cortex radial } \\
\text { glia guided migration }\end{array}$ & 1 & 2 & 50.000 & 0.00321 & 0.026314 \\
\hline SEMA3A; & $\begin{array}{l}\text { GO:0021828 gonadotrophin-releasing } \\
\text { hormone neuronal migration to the } \\
\text { hypothalamus }\end{array}$ & 1 & 2 & 50.000 & 0.00321 & 0.026314 \\
\hline FRMD6; & $\begin{array}{l}\text { GO:0032970 regulation of actin } \\
\text { filament-based process }\end{array}$ & 1 & 2 & 50.000 & 0.00321 & 0.026314 \\
\hline ANK2; & GO:0033292 T-tubule organization & 1 & 3 & 33.333 & 0.00427 & 0.026314 \\
\hline KCNMA1; & $\begin{array}{c}\text { GO:0034465 response to carbon } \\
\text { monoxide }\end{array}$ & 1 & 3 & 33.333 & 0.00427 & 0.026314 \\
\hline ANK2; FRMD6; & $\begin{array}{l}\text { GO:0034613 cellular protein } \\
\text { localization }\end{array}$ & 2 & 40 & 5.000 & 0.00094 & 0.026314 \\
\hline ANK2; & $\begin{array}{c}\text { GO:0036309 protein localization to } \\
\text { M-band }\end{array}$ & 1 & 2 & 50.000 & 0.00321 & 0.026314 \\
\hline
\end{tabular}


Table 4. Cont.

\begin{tabular}{|c|c|c|c|c|c|c|}
\hline Genes & Process_Name & $\begin{array}{l}\text { Significant_ } \\
\text { Genes_Count }\end{array}$ & $\begin{array}{l}\text { Total_Genes_ } \\
\text { Group_Count }\end{array}$ & $\begin{array}{l}\text { Percent__ } \\
\text { Significant_Genes }\end{array}$ & $p$-Value & padj-Value \\
\hline ANK2; & $\begin{array}{c}\text { GO:0036371 protein localization to } \\
\text { T-tubule }\end{array}$ & 1 & 1 & 100.000 & 0.00214 & 0.026314 \\
\hline SEMA3A; & $\begin{array}{l}\text { GO:0036486 ventral trunk neural } \\
\text { crest cell migration }\end{array}$ & 1 & 3 & 33.333 & 0.00427 & 0.026314 \\
\hline SSC5D; & $\begin{array}{l}\text { GO:0042494 detection of bacterial } \\
\text { lipoprotein }\end{array}$ & 1 & 1 & 100.000 & 0.00214 & 0.026314 \\
\hline SEMA3A; & $\begin{array}{c}\text { GO:0048880 sensory system } \\
\text { development }\end{array}$ & 1 & 3 & 33.333 & 0.00427 & 0.026314 \\
\hline SSC5D; DEFA3; & $\begin{array}{l}\text { GO:0050830 defense response to } \\
\text { Gram-positive bacterium }\end{array}$ & 2 & 66 & 3.030 & 0.00245 & 0.026314 \\
\hline
\end{tabular}

padj-value: $p$ value adjustable. 
Table 5. The 20 most significant different pathways between HD gene carries with depression and HD gene carriers without depression

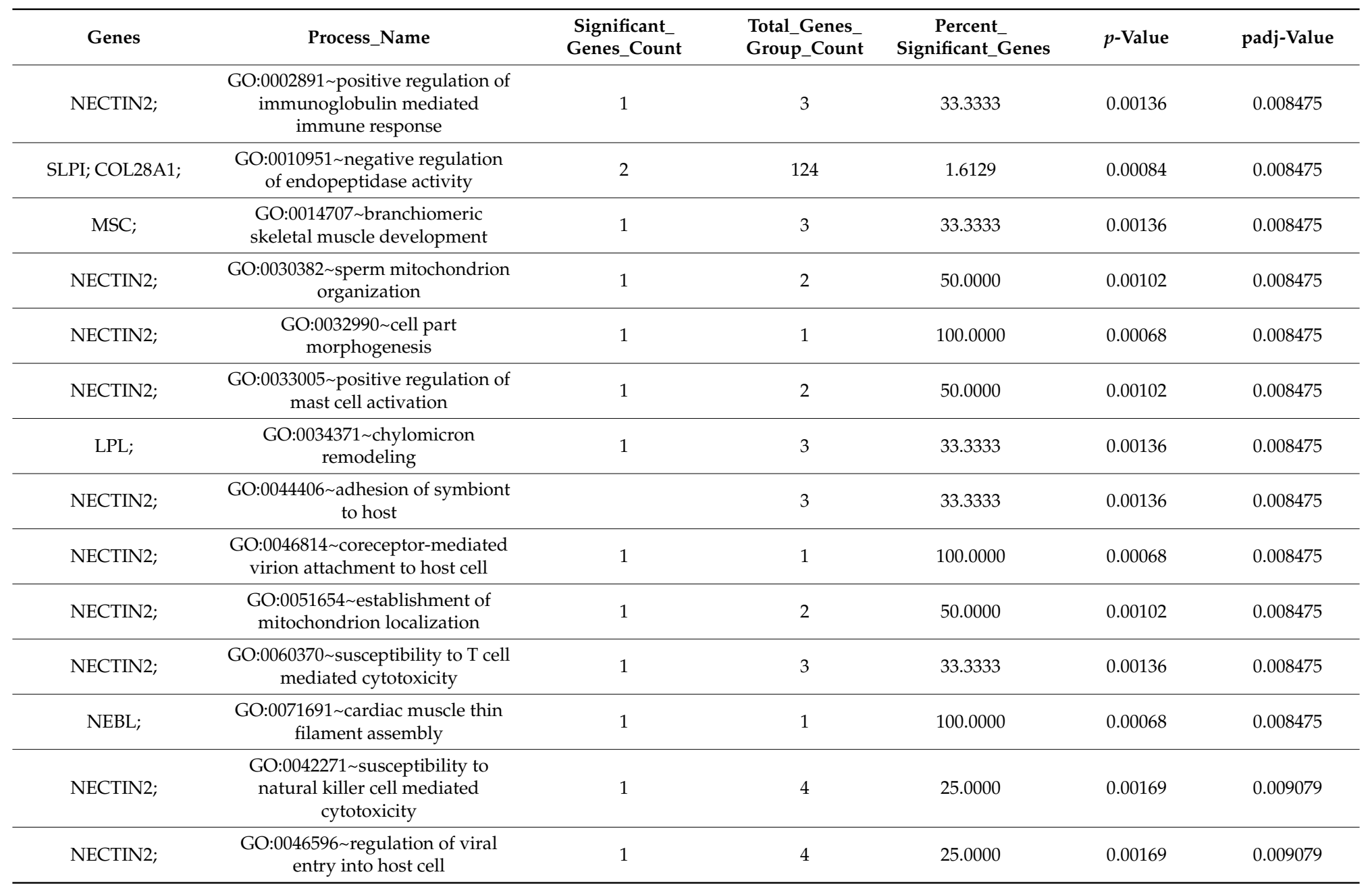


Table 5. Cont.

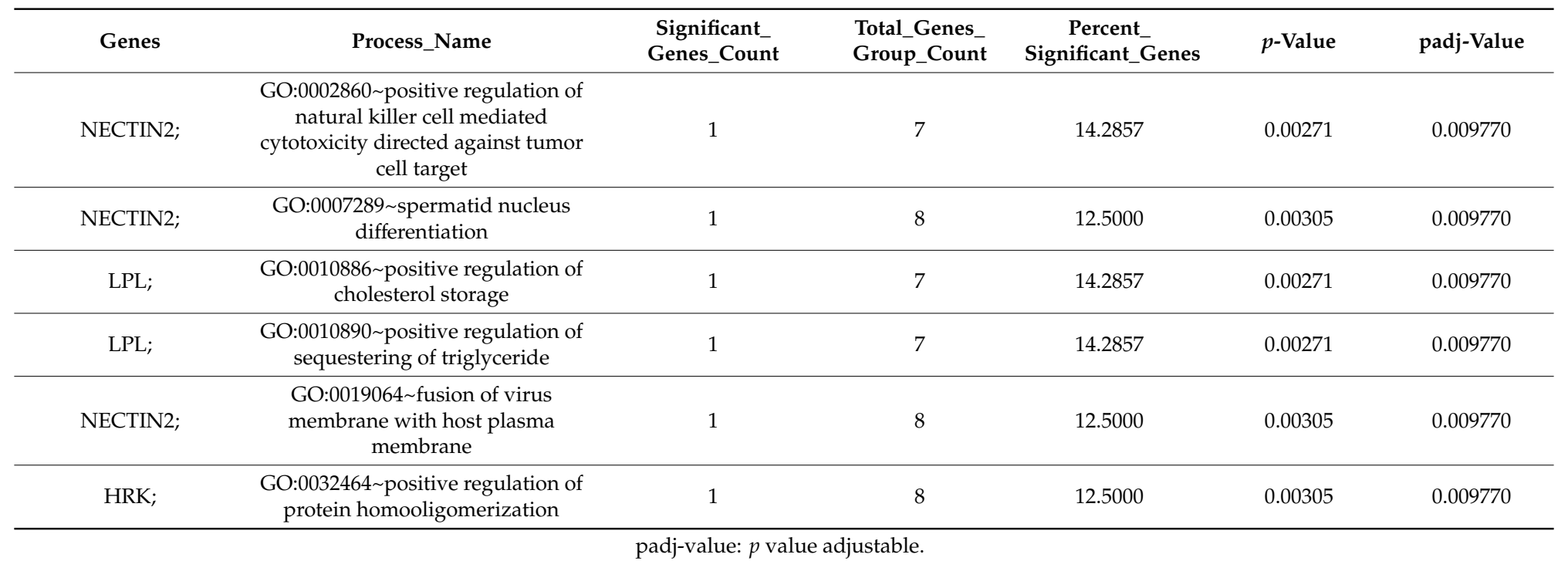

padj-value: $p$ value adjustable. 


\section{Discussion}

In this study, we examined RNA-seq gene expression in the blood of HD gene carriers with and without depressive symptoms and healthy controls. Differences between HD gene carriers and controls were marked, with several genes related to neurodevelopmental pathways. Conversely, differences among HD gene carriers with and without depression were less pronounced. As several of the genes and enriched pathways are involved in the development of the nervous system, our preliminary findings corroborate the emerging view that in addition to being a neurodegenerative disease, HD has a neurodevelopmental component.

The gene B3GAT1 was among the top differentially expressed genes between HD gene carriers and controls. This gene is the key enzyme during the biosynthesis of the carbohydrate epitope HNK-1. The HNK-1 epitope is mainly present in the brain, more specifically in a number of cell adhesion molecules (CAM) important for neuronal cell adhesion, synaptic plasticity, and, therefore, neurodevelopment $[24,25]$. B3GAT1 has also been implicated in major psychiatric disorders, as schizophrenia and schizoaffective disorders [26]. Mice deficient for B3GAT1 exhibited normal development of gross anatomical features, but had impairments of high-order brain functions, including learning, and memory [25].

Another gene differentially expressed between HD gene carriers and healthy controls was ADGRG1 (or GPR56). This gene encodes a member of the G protein-coupled receptor family. ADGRG1 plays critical roles in the development of several organs, including the brain, with extensive implications for human diseases and their treatment [27-31]. Mutations in ADGRG1 cause a severe human brain malformation called bilateral frontoparietal polymicrogyria, characterized by cortical lamination defects, cerebellar hypoplasia, and central nervous system hypomyelination [32,33]. In addition, $A D G R G 1$ regulates embryonic brain development and postnatal myelination [34,35].

Both B3GAT1 and ADGRG1 are involved in neurodevelopment, corroborating recent studies that propose the conceptualization of HD as a neurodevelopmental disease [36,37]. It has been proposed that CAG repeat expansion may be phylogenetically relevant for brain development [38]. Animal models, in vitro studies and molecular research studies have shown that the protein HTT mediates a variety of developmental processes in the central nervous system [36,39]. Accordingly, the presence of mHTT may influence neuronal homeostasis throughout development, ultimately leading to premature cell death and, hence, neurodegeneration from otherwise nonlethal stressors. Importantly, prior to neuronal death, mHTT may cause subclinical neurodevelopmental abnormalities [40,41]. In humans, a study evaluating fractal dimension (FD), a sensitive measure of cortical neurodevelopment, showed that the premanisfest HD subjects differed from healthy controls in the amount of cortical folding in temporal regions, and in motor and visual areas. This spatial pattern of FD differs from what has been observed in well-defined neurodevelopmental disorders such as autism. In this latter case, higher cortical folding was seen in frontal, temporal and parietal regions, and more pronounced in children than in young adults [42]. Altogether these findings suggest that HTT gene expression may be a factor that contributes to cortical development, especially those regions that differ between patients and controls [43].

Comparing HD gene carriers with depression and without depression, one of the top differentially expressed gene was NECTIN2. NECTIN2 is downregulated in HD gene carriers with depression. The correspondent protein is a CAM, i.e., an important structural substrate required for synaptic plasticity and synaptogenesis. NECTIN2 is part of the nectin family of four structurally similar type-I membrane glycoproteins belonging to the immunoglobulin superfamily (IgSF) [44]. CAMs are trans-synaptic anchors and mediators of experience-dependent signaling, dynamically modulating synaptic activity and plasticity $[45,46]$. These proteins participate in synaptogenesis, neural growth, synaptic maturation, and modulate synaptic function through interactions with other synaptic proteins and receptors $[45,47]$. Nectins are also able to interact and activate membrane receptors of different growth factors, such as fibroblast growth factor, platelet-derived growth factor and the vascular endothelial growth factor, regulating proliferation, differentiation, and cell survival [48]. 
These interactions are relevant for depression given the role played by growth factors in its pathophysiology [49].

CAM dysfunction has been associated with several neuropsychiatric conditions [50-53]. In addition, chronic stress can affect the expression of CAMs, with the chronic restraint model of depression leading to decreased expression of CAMs in the hippocampus [52]. This observation goes in line with the concept that neurodevelopmental impairment and/or dysfunction increase the vulnerability to psychiatric disorders by altering the developmental programming of brain regions that are associated with affective and cognitive processing [54-56]. Indeed, the presence of neurodevelopmental abnormalities, notably involving cortical regions, is associated with an increased lifetime risk for depression [54]. The establishment of cortical thickness depends on different processes such as cell death, synaptogenesis, synaptic pruning, and myelination during the first two decades of life, with a dynamic synaptic reorganization modulated by environmental influences [57-60]. Abnormal brain volume has been consistently shown in depression, and a recent meta-analysis including over 10,000 subjects showed cortical abnormalities in adults and adolescents with major depression [61].

We also performed gene ontology (GO) analysis to identify the pathways that are enriched by differently expressed genes. The pathway 'cerebral cortex radial glia guided migration' has the presence of ADGRG1. This pathway is involved in neuronal radial migration in the developing cerebral cortex. The cerebral cortex has a well-organized six-layered architecture. The establishment of cortical layers in the mammal developing cortex requires an elaborate control of multiple processes, such as cell proliferation, differentiation, apoptosis, and neuronal migration [62]. Studies have revealed that radial glia are present during corticogenesis and their processes span the full thickness of the cortical wall [63]. Defects in radial glial cells could lead to cortical heterotopias, suggesting that normal radial glial cells are critical for cerebral cortex development $[64,65]$. One of the pathways containing NECTIN2 is called 'cell part morphogenesis' that refers to how structures of a cell are generated and organized. Altogether, these results implicate the involvement of neurodevelopmental pathways in HD and, more specifically, in the emergence of depression.

Interestingly, another enriched pathway in the comparison among HD carriers was the positive regulation of 'immunoglobulin mediated immune response' in subjects with depression. This pathway has NECTIN2 and is involved in processes that activate or increase the frequency, rate, or extent of an immunoglobulin-mediated immune response. The immune system is a relevant player in the pathological cascade of neurodegenerative diseases triggered by misfolded proteins, including HD [66]. In addition, immune changes have been associated with the pathophysiology of depression [67].

There are limitations in this study that must be considered. First, this is a cross-sectional study with a small sample size. The analyses were performed in the blood and might not accurately reflect alterations in the central nervous system. Despite these shortcomings, this is the first study to compare peripheral (i.e., blood) gene expression profile between HD gene carriers and healthy controls.

In summary, we found distinctive gene expression related to neurodevelopmental pathways in HD. These findings are in line with recent studies suggesting that HD is not only a neurodegenerative disease but also has a neurodevelopmental component. Our findings also suggest that this neurodevelopmental component can contribute to the increased rates of depression in HD. Future directions include analyses of the identified genes in larger cohorts of HD carriers aiming to better understand the pathophysiology and risk factors associated with depression (and other behavioral correlates) in HD.

\section{Material and Methods}

\subsection{Subjects and Clinical Assessments}

This study included 16 patients with a genetic diagnosis of HD (9 premanifest and 7 manifest HD, i.e., patients with a clinical diagnosis of HD), being eight HD gene carriers with symptoms of depression and eight patients without, and a group of 8 healthy controls. HD gene carriers were recruited from 
the Huntington Disease Society of America (HDSA) Center of Excellence at University of Texas Health Science Center at Houston (UTHealth). Controls were recruited from the local community, comprising a group of people with no history of neurological or psychiatric disorders. Genetic diagnosis was confirmed by a genotype CAG allele $\geq 36$. A movement disorders specialist evaluated all patients and the clinical diagnosis of HD was based on established motor signs, i.e., a Diagnostic Confidence Level (DCL) set at 4 in the Unified HD Rating Scale (UHDRS) (1996). All subjects provided written informed consent before admission to the study (Approval Number: HSC-MS-17-0234, and issue on 10 May 2017). The Research Ethics Committees of UTHealth approved this study.

The clinical evaluation included a questionnaire about socio-demographic information alongside motor, cognitive and behavioral assessments. HD gene carriers were subjected to motor function evaluation with the UHDRS (1996). Behavioral symptoms were evaluated through the short version of the Problem Behaviors Assessment (PBS-s). The PBA-s is a semi-structured interview containing 11 items, each designed to measure the severity and frequency of different behavioral symptoms in HD (McNally G et al., 2015). Patients with a score zero or $<2$ were considered without depression symptoms. Patients had moderate to severe symptoms of depression.

\subsection{Blood Sampling}

Peripheral blood was collected from participants by venipuncture into PAXgene Blood RNA Tubes (PreAnalytix, QIAGEN, Inc., Germantown, MD, USA) on the same day of clinical assessment. RNA was isolated with the PreAnalytix kit (QIAGEN, Inc., Germantown, MD, USA) according to the manufacturer's instructions. Total RNA samples were quantified and sent to a core facility to perform RNA-sequencing.

\subsection{Gene Expression Analysis}

RNA samples were quantified upon receipt using Qubit 2.0 Fluorometer (Life Technologies, Carlsbad, CA, USA) and RNA integrity was checked with 4200 TapeStation (Agilent Technologies, Palo Alto, CA, USA). rRNA depletion along with globin depletion was performed using Globin Zero Gold kit (Illumina, San Diego, CA, USA).

RNA sequencing library preparation used NEBNext Ultra RNA Library Prep Kit for Illumina by following the manufacturer's recommendations (NEB, Ipswich, MA, USA). Briefly, enriched RNAs were fragmented for 15 minutes at $94^{\circ} \mathrm{C}$. First strand and second strand cDNA were subsequently synthesized. cDNA fragments were end repaired and adenylated at 3 'ends, and universal adapter was ligated to cDNA fragments, followed by index addition and library enrichment with limited cycle PCR. Sequencing libraries were validated using the Agilent Tapestation 4200 (Agilent Technologies, Palo Alto, CA, USA), and quantified by using Qubit 2.0 Fluorometer (Invitrogen, Carlsbad, CA, USA) as well as by quantitative PCR (Applied Biosystems, Carlsbad, CA, USA).

The sequencing libraries were multiplexed and clustered on two lanes of a flow cell and loaded on the Illumina HiSeq instrument according to manufacturer's instructions. The samples were sequenced using a $2 \times 150$ Paired End (PE) configuration. Image analysis and base calling were conducted by the HiSeq Control Software (HCS). Raw sequence data (.bcl files) generated from Illumina HiSeq were converted into fastq files and de-multiplexed using Illumina's bcl2fastq 2.17 software. One mismatch was allowed for index sequence identification.

\subsection{Data Analysis}

After demultiplexing, sequence data were checked for overall quality and yield. Then, sequence reads were trimmed to remove possible adapter sequences and nucleotides with poor quality using Trimmomatic v.0.36. The trimmed reads were mapped to the Homo sapiens reference genome GRCh38 available on ENSEMBL using the STAR aligner v.2.5.2b. The STAR aligner is a splice aware aligner that detects splice junctions and incorporates them to help align the entire read sequences. BAM files were 
generated as a result of this step. Unique gene hit counts were calculated by using feature Counts from the Subread package v.1.5.2. Only unique reads within exon regions were counted.

After extraction of gene hit counts, the gene hit counts table was used for downstream differential expression analysis. Using DESeq2, a comparison of gene expression between the groups of samples was performed. The Wald test was used to generate $p$-values and Log2 fold changes. Genes with adjusted $p$-values $<0.05$ and absolute $\log 2$ fold changes $>1$ were called as differentially expressed genes for each comparison. A gene ontology analysis was performed on the statistically significant set of genes by implementing the software GeneSCF v1.1. The GO list was used to cluster the set of genes based on their biological process and determine their statistical significance. A PCA analysis was performed using the "plotPCA" function within the DESeq2 R package. The plot shows the samples in a 2D plane spanned by their first two principal components. The top 500 genes, selected by highest row variance, were used to generate the plot.

\subsection{Gene Ontology Analysis}

A gene ontology analysis was performed on the statistically significant set of genes by implementing the software GeneSCF v.1.1-p2. The goa_human GO list was used to cluster the set of genes based on their biological processes and determine their statistical significance. A list of genes clustered based on their gene ontologies was generated, adjusted $p$-value less than 0.05 in the differentially expressed gene sets.

\subsection{Real-Time Quantitative PCR}

Three top differentially expressed genes between groups were selected for validation using real time quantitative PCR. Briefly, RNA samples (300 ng) were initially converted into cDNA using the High Capacity cDNA Synthesis Kit (Life Technologies, Carlsbad, CA) and later diluted 2 times for the PCR reactions. Amplifications of Adhesion G Protein-Coupled Receptor G1 (ADGRG1), Galactosylgalactosylxylosylprotein 3-beta-glucuronosyltransferase 1 (B3GAT1) and Nectin Cell Adhesion Molecule 2 (NECTIN2) were performed in $12 \mu \mathrm{L}$-reactions using inventoried FAM-MGB-labeled TaqMan Gene Expression Assays (Hs00938474_m1, Hs01024500_m1, Hs01071562_m1 for ADGRG1, B3GAT1 and NECTIN2, respectively) and the VIC-MGB_PL-labelled beta-2-microglobulin (B2M) as endogenous control (Hs00187842_m1). PCR reactions were run on a QuantStudio 7 Flex Real-Time PCR System (Life Technologies, Massachusetts, USA) with each sample assayed in triplicate. Data were analyzed by the 2(-Delta Delta C(T)) method.

\subsection{Statistical Analysis}

After extraction of gene hit counts, the gene hit counts table was used for downstream differential expression analysis. Preprocessing of data and between-group comparisons were calculated using DESeq2. The Wald test was used to generate $p$-values and $\log 2$ fold changes. Genes with a $p$-value $<0.05$ and absolute $\log 2$ fold change $>1$ were called as differentially expressed genes. In addition, we clustered differentially expressed genes by their gene ontology (GO) using GeneSCF and the enrichment of GO terms was tested by Fisher exact test. In the PCR results we used t-tests with a significance level of $p<0.05$ were used to evaluate for possible group differences.

Author Contributions: G.D.C. did the genetic analyses and drafted the first version of the manuscript; N.P.R. and E.F.S. recruited all the subjects and contributed to the statistical analysis and writing of the final version of the manuscript; A.L.T. designed the study, oversaw all research steps, and wrote the final version of the manuscript. All authors have read and agreed to the published version of the manuscript.

Funding: This research was funded by the Department of Psychiatry and Behavioral Sciences, UT Health Houston and Huntington's disease Society of America.

Acknowledgments: The Neuropsychiatry Program is partly supported by the Department of Psychiatry and Behavioral Sciences, UT Health Houston. The UT Health Center of Excellence in Huntington's disease is partly funded by the Huntington's disease Society of America. 
Conflicts of Interest: The authors declare no conflict of interest.

\section{References}

1. MacDonald, M.E.; Barnes, G.; Srinidhi, J.; Duyao, M.P.; Ambrose, C.M.; Myers, R.H.; Gray, J.; Conneally, P.M.; Young, A.; Penney, J.; et al. Gametic but not somatic instability of CAG repeat length in Huntington's disease. J. Med. Genet. 1993, 30, 982-986. [CrossRef] [PubMed]

2. Dorsey, E.R.; Beck, C.A.; Darwin, K.; Nichols, P.; Brocht, A.F.; Biglan, K.M.; Shoulson, I.; Huntington Study Group, C.I. Natural history of Huntington disease. JAMA Neurol. 2013, 70, 1520-1530. [CrossRef] [PubMed]

3. Testa, C.M.; Jankovic, J. Huntington disease: A quarter century of progress since the gene discovery. J. Neurol. Sci. 2019, 396, 52-68. [CrossRef] [PubMed]

4. Nasir, J.; Floresco, S.B.; O’Kusky, J.R.; Diewert, V.M.; Richman, J.M.; Zeisler, J.; Borowski, A.; Marth, J.D.; Phillips, A.G.; Hayden, M.R. Targeted disruption of the Huntington's disease gene results in embryonic lethality and behavioral and morphological changes in heterozygotes. Cell 1995, 81, 811-823. [CrossRef]

5. Dietrich, P.; Shanmugasundaram, R.; Shuyu, E.; Dragatsis, I. Congenital hydrocephalus associated with abnormal subcommissural organ in mice lacking huntingtin in Wnt1 cell lineages. Hum. Mol. Genet. 2009, 18, 142-150. [CrossRef]

6. Taran, A.S.; Shuvalova, L.D.; Lagarkova, M.A.; Alieva, I.B. Huntington's Disease-An Outlook on the Interplay of the HTT Protein, Microtubules and Actin Cytoskeletal Components. Cells 2020, 9, 1514. [CrossRef] [PubMed]

7. Dragatsis, I.; Levine, M.S.; Zeitlin, S. Inactivation of Hdh in the brain and testis results in progressive neurodegeneration and sterility in mice. Nat. Genet. 2000, 26, 300-306. [CrossRef]

8. Zuccato, C.; Valenza, M.; Cattaneo, E. Molecular mechanisms and potential therapeutical targets in Huntington's disease. Physiol. Rev. 2010, 90, 905-981. [CrossRef]

9. Ross, C.A.; Reilmann, R.; Cardoso, F.; McCusker, E.A.; Testa, C.M.; Stout, J.C.; Leavitt, B.R.; Pei, Z.; Landwehrmeyer, B.; Martinez, A.; et al. Movement Disorder Society Task Force Viewpoint: Huntington's Disease Diagnostic Categories. Mov. Disord. Clin. Pract. 2019, 6, 541-546. [CrossRef]

10. Reedeker, W.; van der Mast, R.C.; Giltay, E.J.; Kooistra, T.A.; Roos, R.A.; van Duijn, E. Psychiatric disorders in Huntington's disease: A 2-year follow-up study. Psychosomatics 2012, 53, 220-229. [CrossRef]

11. Duff, K.; Paulsen, J.S.; Beglinger, L.J.; Langbehn, D.R.; Stout, J.C.; Predict, H.D.I.o.t.H.S.G. Psychiatric symptoms in Huntington's disease before diagnosis: The predict-HD study. Biol. Psychiatry 2007, 62, 1341-1346. [CrossRef] [PubMed]

12. Ho, A.K.; Gilbert, A.S.; Mason, S.L.; Goodman, A.O.; Barker, R.A. Health-related quality of life in Huntington's disease: Which factors matter most? Mov. Disord. Off. J. Mov. Disord. Soc. 2009, 24, 574-578. [CrossRef] [PubMed]

13. Wetzel, H.H.; Gehl, C.R.; Dellefave-Castillo, L.; Schiffman, J.F.; Shannon, K.M.; Paulsen, J.S.; Huntington Study Group. Suicidal ideation in Huntington disease: The role of comorbidity. Psychiatry Res. 2011, 188, 372-376. [CrossRef] [PubMed]

14. Farrer, L.A. Suicide and attempted suicide in Huntington disease: Implications for preclinical testing of persons at risk. Am. J. Med Genet. 1986, 24, 305-311. [CrossRef] [PubMed]

15. Robins Wahlin, T.B.; Backman, L.; Lundin, A.; Haegermark, A.; Winblad, B.; Anvret, M. High suicidal ideation in persons testing for Huntington's disease. Acta Neurol. Scand. 2000, 102, 150-161. [CrossRef]

16. Schoenfeld, M.; Myers, R.H.; Cupples, L.A.; Berkman, B.; Sax, D.S.; Clark, E. Increased rate of suicide among patients with Huntington's disease. J. Neurol. Neurosurg. Psychiatry 1984, 47, 1283-1287. [CrossRef]

17. Fiedorowicz, J.G.; Mills, J.A.; Ruggle, A.; Langbehn, D.; Paulsen, J.S.; Group, P.-H.I.o.t.H.S. Suicidal behavior in prodromal Huntington disease. Neuro Degener. Dis. 2011, 8, 483-490. [CrossRef]

18. Almqvist, E.W.; Brinkman, R.R.; Wiggins, S.; Hayden, M.R. Canadian Collaborative Study of Predictive, T. Psychological consequences and predictors of adverse events in the first 5 years after predictive testing for Huntington's disease. Clin. Genet. 2003, 64, 300-309. [CrossRef]

19. Van Duijn, E.; Kingma, E.M.; Timman, R.; Zitman, F.G.; Tibben, A.; Roos, R.A.; van der Mast, R.C. Cross-sectional study on prevalences of psychiatric disorders in mutation carriers of Huntington's disease compared with mutation-negative first-degree relatives. J. Clin. Psychiatry 2008, 69, 1804-1810. [CrossRef] 
20. Berrios, G.E.; Wagle, A.C.; Markova, I.S.; Wagle, S.A.; Ho, L.W.; Rubinsztein, D.C.; Whittaker, J.; Ffrench-Constant, C.; Kershaw, A.; Rosser, A.; et al. Psychiatric symptoms and CAG repeats in neurologically asymptomatic Huntington's disease gene carriers. Psychiatry Res. 2001, 102, 217-225. [CrossRef]

21. Craufurd, D.; Thompson, J.C.; Snowden, J.S. Behavioral changes in Huntington Disease. Neuropsychiatry Neuropsychol. Behav. Neurol. 2001, 14, 219-226. [PubMed]

22. Kingma, E.M.; van Duijn, E.; Timman, R.; van der Mast, R.C.; Roos, R.A. Behavioural problems in Huntington's disease using the Problem Behaviours Assessment. Gen. Hosp. Psychiatry 2008, 30, 155-161. [CrossRef] [PubMed]

23. Pla, P.; Orvoen, S.; Saudou, F.; David, D.J.; Humbert, S. Mood disorders in Huntington's disease: From behavior to cellular and molecular mechanisms. Front. Behav. Neurosci. 2014, 8, 135. [CrossRef] [PubMed]

24. Kleene, R.; Schachner, M. Glycans and neural cell interactions. Nat. Rev. Neurosci. 2004, 5, 195-208. [CrossRef]

25. Morita, I.; Kizuka, Y.; Kakuda, S.; Oka, S. Expression and function of the HNK-1 carbohydrate. J. Biochem. 2008, 143, 719-724. [CrossRef]

26. Jeffries, A.R.; Mungall, A.J.; Dawson, E.; Halls, K.; Langford, C.F.; Murray, R.M.; Dunham, I.; Powell, J.F. beta-1,3-Glucuronyltransferase-1 gene implicated as a candidate for a schizophrenia-like psychosis through molecular analysis of a balanced translocation. Mol. Psychiatry 2003, 8, 654-663. [CrossRef]

27. Hamann, J.; Aust, G.; Arac, D.; Engel, F.B.; Formstone, C.; Fredriksson, R.; Hall, R.A.; Harty, B.L.; Kirchhoff, C.; Knapp, B.; et al. International Union of Basic and Clinical Pharmacology. XCIV. Adhesion G protein-coupled receptors. Pharmacol. Rev. 2015, 67, 338-367. [CrossRef]

28. Moreno, M.; Pedrosa, L.; Pare, L.; Pineda, E.; Bejarano, L.; Martinez, J.; Balasubramaniyan, V.; Ezhilarasan, R.; Kallarackal, N.; Kim, S.H.; et al. GPR56/ADGRG1 Inhibits Mesenchymal Differentiation and Radioresistance in Glioblastoma. Cell Rep. 2017, 21, 2183-2197. [CrossRef]

29. Bahi-Buisson, N.; Poirier, K.; Boddaert, N.; Fallet-Bianco, C.; Specchio, N.; Bertini, E.; Caglayan, O.; Lascelles, K.; Elie, C.; Rambaud, J.; et al. GPR56-related bilateral frontoparietal polymicrogyria: Further evidence for an overlap with the cobblestone complex. Brain A J. Neurol. 2010, 133, 3194-3209. [CrossRef]

30. Bae, B.I.; Tietjen, I.; Atabay, K.D.; Evrony, G.D.; Johnson, M.B.; Asare, E.; Wang, P.P.; Murayama, A.Y.; Im, K.; Lisgo, S.N.; et al. Evolutionarily dynamic alternative splicing of GPR56 regulates regional cerebral cortical patterning. Science 2014, 343, 764-768. [CrossRef]

31. Zhu, B.; Luo, R.; Jin, P.; Li, T.; Oak, H.C.; Giera, S.; Monk, K.R.; Lak, P.; Shoichet, B.K.; Piao, X. GAIN domain-mediated cleavage is required for activation of $G$ protein-coupled receptor 56 (GPR56) by its natural ligands and a small-molecule agonist. J. Biol. Chem. 2019, 294, 19246-19254. [CrossRef] [PubMed]

32. Piao, X.; Hill, R.S.; Bodell, A.; Chang, B.S.; Basel-Vanagaite, L.; Straussberg, R.; Dobyns, W.B.; Qasrawi, B.; Winter, R.M.; Innes, A.M.; et al. G protein-coupled receptor-dependent development of human frontal cortex. Science 2004, 303, 2033-2036. [CrossRef] [PubMed]

33. Piao, X.; Chang, B.S.; Bodell, A.; Woods, K.; Benzeev, B.; Topcu, M.; Guerrini, R.; Goldberg-Stern, H.; Sztriha, L.; Dobyns, W.B.; et al. Genotype-phenotype analysis of human frontoparietal polymicrogyria syndromes. Ann. Neurol. 2005, 58, 680-687. [CrossRef] [PubMed]

34. Giera, S.; Deng, Y.; Luo, R.; Ackerman, S.D.; Mogha, A.; Monk, K.R.; Ying, Y.; Jeong, S.J.; Makinodan, M.; Bialas, A.R.; et al. The adhesion G protein-coupled receptor GPR56 is a cell-autonomous regulator of oligodendrocyte development. Nat. Commun. 2015, 6, 6121. [CrossRef]

35. Giera, S.; Luo, R.; Ying, Y.; Ackerman, S.D.; Jeong, S.J.; Stoveken, H.M.; Folts, C.J.; Welsh, C.A.; Tall, G.G.; Stevens, B.; et al. Microglial transglutaminase-2 drives myelination and myelin repair via GPR56/ADGRG1 in oligodendrocyte precursor cells. Elife 2018, 7, e33385. [CrossRef]

36. Wiatr, K.; Szlachcic, W.J.; Trzeciak, M.; Figlerowicz, M.; Figiel, M. Huntington Disease as a Neurodevelopmental Disorder and Early Signs of the Disease in Stem Cells. Mol. Neurobiol. 2018, 55, 3351-3371. [CrossRef]

37. Van der Plas, E.; Langbehn, D.R.; Conrad, A.L.; Koscik, T.R.; Tereshchenko, A.; Epping, E.A.; Magnotta, V.A.; Nopoulos, P.C. Abnormal brain development in child and adolescent carriers of mutant huntingtin. Neurology 2019, 93, e1021-e1030. [CrossRef]

38. Cattaneo, E.; Zuccato, C.; Tartari, M. Normal huntingtin function: An alternative approach to Huntington's disease. Nat. Rev. Neurosci. 2005, 6, 919-930. [CrossRef]

39. Reiner, A.; Dragatsis, I.; Zeitlin, S.; Goldowitz, D. Wild-type huntingtin plays a role in brain development and neuronal survival. Mol. Neurobiol. 2003, 28, 259-276. [CrossRef] 
40. Nopoulos, P.C. Huntington disease: A single-gene degenerative disorder of the striatum. Dialogues Clin. Neurosci. 2016, 18, 91-98.

41. Mehler, M.F.; Gokhan, S. Mechanisms underlying neural cell death in neurodegenerative diseases: Alterations of a developmentally-mediated cellular rheostat. Trends Neurosci. 2000, 23, 599-605. [CrossRef]

42. Awate, S.P.; Win, L.; Yushkevich, P.; Schultz, R.T.; Gee, J.C. 3D cerebral cortical morphometry in autism: Increased folding in children and adolescents in frontal, parietal, and temporal lobes. Med. Image Comput. Comput. Assist. Interv. 2008, 11, 559-567. [CrossRef] [PubMed]

43. Kubera, K.M.; Schmitgen, M.M.; Hirjak, D.; Wolf, R.C.; Orth, M. Cortical neurodevelopment in pre-manifest Huntington's disease. Neuroimage Clin. 2019, 23, 101913. [CrossRef] [PubMed]

44. Harrison, O.J.; Vendome, J.; Brasch, J.; Jin, X.; Hong, S.; Katsamba, P.S.; Ahlsen, G.; Troyanovsky, R.B.; Troyanovsky, S.M.; Honig, B.; et al. Nectin ectodomain structures reveal a canonical adhesive interface. Nat. Struct. Mol. Biol. 2012, 19, 906-915. [CrossRef]

45. Dalva, M.B.; McClelland, A.C.; Kayser, M.S. Cell adhesion molecules: Signalling functions at the synapse. Nat. Rev. Neurosci. 2007, 8, 206-220. [CrossRef]

46. Shapiro, L. Self-recognition at the atomic level: Understanding the astonishing molecular diversity of homophilic Dscams. Neuron 2007, 56, 10-13. [CrossRef]

47. Parrish, J.Z.; Emoto, K.; Kim, M.D.; Jan, Y.N. Mechanisms that regulate establishment, maintenance, and remodeling of dendritic fields. Annu. Rev. Neurosci. 2007, 30, 399-423. [CrossRef]

48. Mizutani, K.; Takai, Y. Nectin spot: A novel type of nectin-mediated cell adhesion apparatus. Biochem. J. 2016, 473, 2691-2715. [CrossRef]

49. Audet, M.C.; Anisman, H. Interplay between pro-inflammatory cytokines and growth factors in depressive illnesses. Front. Cell. Neurosci. 2013, 7, 68. [CrossRef]

50. Jamain, S.; Quach, H.; Betancur, C.; Rastam, M.; Colineaux, C.; Gillberg, I.C.; Soderstrom, H.; Giros, B.; Leboyer, M.; Gillberg, C.; et al. Mutations of the X-linked genes encoding neuroligins NLGN3 and NLGN4 are associated with autism. Nat. Genet. 2003, 34, 27-29. [CrossRef]

51. Kirov, G.; Gumus, D.; Chen, W.; Norton, N.; Georgieva, L.; Sari, M.; O’Donovan, M.C.; Erdogan, F.; Owen, M.J.; Ropers, H.H.; et al. Comparative genome hybridization suggests a role for NRXN1 and APBA2 in schizophrenia. Hum. Mol. Genet. 2008, 17, 458-465. [CrossRef] [PubMed]

52. Sandi, C. Stress, cognitive impairment and cell adhesion molecules. Nat. Rev. Neurosci. 2004, 5, 917-930. [CrossRef] [PubMed]

53. Yan, J.; Oliveira, G.; Coutinho, A.; Yang, C.; Feng, J.; Katz, C.; Sram, J.; Bockholt, A.; Jones, I.R.; Craddock, N.; et al. Analysis of the neuroligin 3 and 4 genes in autism and other neuropsychiatric patients. Mol. Psychiatry 2005, 10, 329-332. [CrossRef] [PubMed]

54. Peterson, B.S.; Wang, Z.; Horga, G.; Warner, V.; Rutherford, B.; Klahr, K.W.; Graniello, B.; Wickramaratne, P.; Garcia, F.; Yu, S.; et al. Discriminating risk and resilience endophenotypes from lifetime illness effects in familial major depressive disorder. JAMA Psychiatry 2014, 71, 136-148. [CrossRef]

55. Gee, D.G.; Casey, B.J. The Impact of Developmental Timing for Stress and Recovery. Neurobiol. Stress 2015, 1, 184-194. [CrossRef]

56. McLaughlin, K.A.; Koenen, K.C.; Bromet, E.J.; Karam, E.G.; Liu, H.; Petukhova, M.; Ruscio, A.M.; Sampson, N.A.; Stein, D.J.; Aguilar-Gaxiola, S.; et al. Childhood adversities and post-traumatic stress disorder: Evidence for stress sensitisation in the World Mental Health Surveys. Br. J. Psychiatry J. Ment. Sci. 2017, 211, 280-288. [CrossRef]

57. Hirjak, D.; Huber, M.; Kirchler, E.; Kubera, K.M.; Karner, M.; Sambataro, F.; Freudenmann, R.W.; Wolf, R.C. Cortical features of distinct developmental trajectories in patients with delusional infestation. Prog. Neuro Psychopharmacol. Biol. Psychiatry 2017, 76, 72-79. [CrossRef]

58. Oostermeijer, S.; Whittle, S.; Suo, C.; Allen, N.B.; Simmons, J.G.; Vijayakumar, N.; van de Ven, P.M.; Jansen, L.M.; Yucel, M.; Popma, A. Trajectories of adolescent conduct problems in relation to cortical thickness development: A longitudinal MRI study. Transl. Psychiatry 2016, 6, e899. [CrossRef]

59. Vijayakumar, N.; Allen, N.B.; Youssef, G.; Dennison, M.; Yucel, M.; Simmons, J.G.; Whittle, S. Brain development during adolescence: A mixed-longitudinal investigation of cortical thickness, surface area, and volume. Hum. Brain Mapp. 2016, 37, 2027-2038. [CrossRef]

60. Zilles, K.; Palomero-Gallagher, N.; Amunts, K. Development of cortical folding during evolution and ontogeny. Trends Neurosci. 2013, 36, 275-284. [CrossRef] 
61. Schmaal, L.; Hibar, D.P.; Samann, P.G.; Hall, G.B.; Baune, B.T.; Jahanshad, N.; Cheung, J.W.; van Erp, T.G.M.; Bos, D.; Ikram, M.A.; et al. Cortical abnormalities in adults and adolescents with major depression based on brain scans from 20 cohorts worldwide in the ENIGMA Major Depressive Disorder Working Group. Mol. Psychiatry 2017, 22, 900-909. [CrossRef] [PubMed]

62. Barkovich, A.J.; Guerrini, R.; Kuzniecky, R.I.; Jackson, G.D.; Dobyns, W.B. A developmental and genetic classification for malformations of cortical development: Update 2012. Brain A J. Neurol. 2012, 135, 1348-1369. [CrossRef] [PubMed]

63. Misson, J.P.; Austin, C.P.; Takahashi, T.; Cepko, C.L.; Caviness, V.S., Jr. The alignment of migrating neural cells in relation to the murine neopallial radial glial fiber system. Cereb. Cortex 1991, 1, 221-229. [CrossRef] [PubMed]

64. Jossin, Y.; Lee, M.; Klezovitch, O.; Kon, E.; Cossard, A.; Lien, W.H.; Fernandez, T.E.; Cooper, J.A.; Vasioukhin, V. Llgl1 Connects Cell Polarity with Cell-Cell Adhesion in Embryonic Neural Stem Cells. Dev. Cell 2017, 41, 481-495. e485. [CrossRef] [PubMed]

65. Beattie, R.; Hippenmeyer, S. Mechanisms of radial glia progenitor cell lineage progression. FEBS Lett. 2017, 591, 3993-4008. [CrossRef] [PubMed]

66. Ramsingh, A.I.; Manley, K.; Rong, Y.; Reilly, A.; Messer, A. Transcriptional dysregulation of inflammatory/immune pathways after active vaccination against Huntington's disease. Hum. Mol. Genet. 2015, 24, 6186-6197. [CrossRef]

67. Colpo, G.D.; Leboyer, M.; Dantzer, R.; Trivedi, M.H.; Teixeira, A.L. Immune-based strategies for mood disorders: Facts and challenges. Expert Rev. Neurother. 2017, 18, 139-152. [CrossRef]

Publisher's Note: MDPI stays neutral with regard to jurisdictional claims in published maps and institutional affiliations. 